\title{
Desain Pembelajaran Pendidikan Agama Islam Berbasis Kesadaran Lingkungan
}

Mundiro Lailatul muawaroh

Sekolah tinggi ilmu Tarbiyah AL-Ibrohimy bangkalan elapersia7@gmail.com

\section{Article History:}

Received: 09-02-2019

Revised: 15-02-2019

Accepted: 10-03-2019

\begin{abstract}
The low level of concern for the environment in society today is increasingly worrying. This reality has resulted in the emergence of several disasters caused by the lack of awareness about environmental sustainability. In this context, students' misunderstanding of the importance of protecting the school environment encourages the creation of a sense of indifference to create a comfortable school environment. Education can be used as a tool to foster love and awareness to manage the environment. This research uses qualitative research with descriptive analysis intended to reveal the phenomena that occur in the school environment related to environmental awareness. The data in this study were obtained through observation, interviews and documentation. Data analysis was performed by data reduction, data presentation and verification. Checking the validity of the data is done by conducting triangulation and member check. This study found that the learning process of PAI with environmental awareness can be done with a teaching design that emphasizes environmental awareness issues, both in the media, methods and learning materials. Environmental awareness-based PAI instructional design requires an educator to package learning, both in introductory, core and closing activities. The flow of this activity, then what makes students' understanding and attitudes related to environmental sustainability can develop well.
\end{abstract}

Keyword: Learning Design, Islamic Education, Environmental Awareness

\section{Pendahuluan}

Pendidikan sampai saat ini masih dipercaya sebagai suatu media yang ampuh dalam membangun kecerdasan sekaligus kepribadian anak manusia menjadi lebih baik. Pendidikan adalah usaha manusia untuk menumbuhkan dan mengembangkan potensipotensi pembawaan, baik jasmani maupun rohani sesuai dengan nilai-nilai yang ada dalam masyarakat dan kebudayaan. ${ }^{1}$

Fenomena industrialisasi telah merasuki sebagian besar dunia ketiga termasuk Indonesia. Disisi lain kemajuan industri yang begitu cepat telah membawa dampak negatif terhadap lingkungan hidup. Bencana ekologis yang terjadi di Indonesia meningkat dari tahun ke tahun menjadi fakta yang tak terbantahkan. Masih meluasnya kerusakan daerah aliran sungai, laju kerusakan hutan, kerusakan lingkungan hidup

\footnotetext{
${ }^{1}$ M. Djumransjah, Filsafat Pendidikan (Malang: Bayumedia Publishing, 2004), 22
} 
menjadi penyebab tingginya bencana iklim. Padahal kelangsungan hidup manusia sangat bergantung pada kelestarian ekosistemnya.

Berbagai macam cara untuk menyelesaikan permasalahan lingkungan hidup telah dilakukan, penanganan dengan pendekatan teknik-intelektual sudah banyak diupayakan.

Fakta rendahnya kepedulian terhadap lingkungan dan kemalasan membuang sampah merupakan faktor internal yang menjadi masalah di berbagai tempat, termasuk di lingkungan. Selain berdampak buruk bagi kesehatan, sampah juga mengganggu kenyamanan proses belajar mengajar siswa. Ketidakpahaman siswa mengenai pentingnya menjaga lingkungan sekolah mendorong terciptanya rasa ketidakperdulian dalam upaya menciptakan lingkungan sekolah yang nyaman.

Kesadaran lingkungan secara umum dipengaruhi oleh banyak faktor seperti faktor ketidaktahuan, faktor kemampuan, faktor gaya hidup, faktor lingkungan tempat tinggal dan faktor lainnya. ${ }^{2}$ Sedangkan kesadaran lingkungan sekolah pada siswa dapat ditanamkan melalui pendidikan yang ada di sekolah terutama pada Pendidikan Agama Islam.

Perwujudan pendidikan agama Islam dalam usaha pelestarian lingkungan yaitu terselenggaranya lembaga pendidikan yang berwawasan lingkungan. Pada tahun 1996 disepakati kerjasama pertama antara Dapartemen Pendidikan Nasional dan Kementerian Negara Lingkungan Hidup, yang diperbaharui pada tahun 2005 dan tahun 2010. Sebagai tindak lanjut dari kesepatakan tahun 2005, pada tahun 2006 Kementerian Lingkungan Hidup mengembangkan program pendidikan lingkungan hidup pada jenjang pendidikan dasar dan menengah melalui program Adiwiyata. ${ }^{3}$ Tujuan dari program Adiwiyata adalah mewujudkan warga sekolah yang bertanggung jawab dalam upaya perlindungan dan pengelolaan lingkungan hidup melalui tata kelola sekolah yang baik untuk mendukung pengembangan berkelanjutan.

Dalam kegiatan pembelajaran masing-masing guru membuat satu rencana pembelajaran yang memuat tentang materi cinta lingkungan yang didesain dalam kegiatan pembelajaran dengan tujuan wawasan kesadaran lingkungan hidup yang diintegrasikan melalui kegiatan pembelajaran tersebut agar menjadikan peserta didik lebih mencintai lingkungannya. Begitu pula dengan mata pelajaran Pendidikan Agama Islam (PAI) yang didalamnya juga mengintegrasikan aspek-aspek lingkungan hidup yang diwujudkan dalam desain atau rencana pelaksanaan pembelajaran yang akan dilaksanakan.

Dari uraian di atas jelaslah Pendidikan Agama Islam dan kesadaran memiliki kaitan yang erat dalam mengatasi krisis lingkungan dewasa ini. Pendidikan berkaitan dengan fungsi intelektualnya melalui proses pendidikan sedangkan agam Islam berkaitan dengan fungsi kesadaran etis. Berdasarkan konteks ini, Pendidikan Agama Islam diharapkan mengembangkan kesadaran, pengetahuan, sikap, keterampilan, dan partisipai peserta didik terhadapan wawasan lingkungan hidup dan permasalahannya

${ }^{2}$ Amos Neolaka, Kesadaran Lingkungan (Jakarta:Rineka Cipta, 2008), 18

3 Pande Made Kutanegara et al, Membangun Masyarakat Indonesia Peduli Lingkungan (Yogyakarta: Gadjah Mada University Press, 2014), 42 
melalui materi-materi dari kurikulum yang semuanya didasarkan pada ajaran Islam yang bersumber al-Qur'an dan Hadits. ${ }^{4}$

Penelitian ini tergolong sebagai penelitian lapangan (field research) yakni penelitian yang langsung dilakukan atau pada responden yang memiliki tujuan untuk mempelajari secara intensif tentang latar belakang sekarang, dan interaksi sosial, individu kelompok, dan masyarakat. ${ }^{5}$ Oleh karena itu, obyek penelitiannya adalah berupa obyek di lapangan yang mampu memberikan informasi tentang kajian penelitian. Dalam hal ini menjadikan SMA Negeri 1 Kedungpring sebagai obyek penelitian. Penelitian ini termasuk dalam penelitian kualitatif yang bermaksud untuk memahami fenomena tentang apa yang dialami oleh subjek penelitian dan dengan cara deskripsi dalam bentuk kata-kata dan bahasa. Pengumpulan datanya menggunakan metode observasi, wawancara, dan dokumentasi sedangkan analisisnya bersifat deskriptif yang ditujukan untuk mendeskripsikan dan menganalisis diharapkan mampu mencapai tujuan penelitian. Subyek penelitian atau responden ini meliputi guru PAI, dan pesera didik.

\section{Konsep Pembelajaran: Tinjauan Teoritik}

Kata pembelajaran berasal dari kata dasar belajar, dalam arti sempit, pembelajaran merupakan suatu proses belajar agar seseorang dapat melakukan kegiatan belajar. Sedangkan belajar adalah suatu proses perubahan tingkah laku karena interaksi individu dengan lingkungan dan pengalaman. ${ }^{6}$ Selain itu terdapat pengertian lain mengenai pembelajaran yaitu pembelajaran merupakan suatu proses dua arah, mengajar dilakukan oleh guru sebagai pendidik, sedangkan belajar dilakukan oleh peserta didik atau murid. Konsep pembelajaran menurut Corey adalah suatu proses dimana lingkungan seseorang secara sengaja di kelolah untuk memungkinkan ia turut serta dalam tingkah laku tersebut dalam kondisi kondisi khusus dari pendidikan. ${ }^{7}$

Sedangkan menurut Gagne dan Briggs, pembelajaran merupakan suatu sistem yang bertujuan untuk membantu proses belajar anak didik, yang dirancang, sedemikian rupa mendukung terjadinya proses belajar anak didik yang bersifat internal. ${ }^{8}$

Dari beberapa pendapat tersebut, maka dapat disimpulkan bahwa, pembelajaran merupakan proses yang dilakukan oleh pendidik untuk membelajarkan peserta didik pada lingkungan belajar tertentu dan akhirnya terjadi perubahan tingkah laku. Oleh karena pembelajaran merupakan proses, tentu dalam sebuah proses terdapat komponen-komponen yang saling terkait. Komponen-komponen pokok dalam pembelajaran mencakup tujuan pembelajaran, pendidik, peserta didik, kurikulum, strategi pembelajaran, media pembelajaran, dan evaluasi pembelajaran. ${ }^{9}$ hubungan

${ }^{4}$ H. Abu Tauhied, Beberapa Aspek Pendidikan Islam (Yogyakarta: Fak. Tarbiyah UIN Sunan Kalijaga, 1990), 16

${ }^{5}$ Nasution, Metode Penelitian Naturalistic Kualitatif (Bandung: Tarsito, 2002), 90

${ }^{6}$ Zainal Arifin, Evaluasi Pembelajara, (Bandung: PT Remaja Rosdakarya, 2012), 10

${ }^{7}$ Dr. H. Syaiful Sagala, Konsep dan Makna Pembelajaran, (Bandung : ALFABETA, 2008), 61

${ }^{8}$ Syaiful Bahri Djamarah, Guru dan Anak Didik, (Jakarta: Rineka Cipta, 2010),325

${ }^{9}$ Glendoni, Komponen-Komponen Pembelajaran, diakses 30 Oktober 2013 
antara komponen-komponen pembelajaran tersebut salah satunya akan membentuk suatu kegiatan yang bernama proses pembelajaran.

Proses pembelajaran merupakan keseluruhan kegiatan yang dirancang untuk membelajarkan peserta didik. Pada satuan pendidikan, proses pembelajaran diselenggarakan secara interaktif, inspiratif, menyenangkan, menantang, memotivasi peserta didik untuk berpartisipasi aktif sesuai dengan bakat, minat dan perkembangan fisik serta psikologis peserta didik. ${ }^{10}$ Di Indonesia Proses pembelajaran pada satuan pendidikan dasar dan menengah diatur dalam standar proses.

Berdasarkan Peraturan Menteri Pendidikan Nasional (Permendiknas) Nomor 41 tahun 2007 tentang standar proses untuk satuan pendidikan dasar dan menengah, bahwa standar proses berisi kriteria minimal proses pembelajaran pada satuan pendidikan dasar dan menengah diseluruh wilayah hukum Negara Kesatuan Republik Indonesia. Standar proses meliputi perencanaan proses pembelajaran, pelaksanaan proses pembelajaran, penilaian hasil pembelajaran, dan pengawasan hasil pembelajaran untuk terlaksananya proses pembelajaran yang efektif dan efisien. ${ }^{11}$

Pelaksanaan proses pembelajaran menjadi komponen yang sangat penting dalam mewujudkan kualitas out put pendidikan. Oleh karena itu, pelaksanaan proses pembelajaran harus dilaksanakan secara tepat ideal dan prosporsional.. ${ }^{12}$ Dengan demikian, guru harus mampu mengimplementasikan teori yang berkaitan dengan teori pembelajaran ke dalam realitas pembelajaran yang sebenarnya. Menurut Roy R.Lefrancois (dikutip oleh Dimyati Mahmud), menyatakan bahwa, pelaksanaan pembelajaran adalah pelaksanaan strategi-strategi yang telah dirancang untuk mencapai tujuan pembelajaran.

Dalam pelaksanaan pembelajaran meliputi kegiatan membuka sampai menutup pelajaran, yang terbagi menjadi kegiatan pendahuluan, kegiatan inti dan kegiatan penutup.

1. Kegiatan Pendahuluan

Dalam kegiatan pendahuluan guru melakukan kegiatan yang meliputi mempersiapkan peserta didik untuk mengikuti proses pembelajaran, melakukan apersepsi (mengaitkan dengan materi sebelumnya dengan materi yang akan dipelajari), menjelaskan tujuan pembelajaran, dan menjelaskan uraian materi sesuai silabus.

2. Kegiatan Inti

Pelaksanaan kegiatan inti merupakan proses pembelajaran untuk mencapai Kompetensi Dasar (KD). Kegiatan inti menggunakan metode yang disesuaikan dengan karakteristik peserta didik dan mata pelajaran. Kegiatan inti meliputi proses eksplorasi, elaborasi dan konfirmasi.

\footnotetext{
${ }^{10}$ Dedi Mulyasana, Pendidikan Bermutu dan Berdaya Saing, (Bandung: PT. Remaja Rosdakarya, 2012), 155

${ }^{11}$ Peraturan Menteri Pendidikan Nasional No.41 tahun 2007 pasal 1 tentang standar proses penmbelajaran untuk satuan menengah

${ }^{12}$ M. Saekhan Munchit, Pembelajaran Konstekstual, (Semarang: RaSAIL Media Group, 2008), 109
} 
3. Kegiatan Penutup

Kegiatan penutup meliputi kegiatan menyimpulkan hasil pembelajaran yang telah dilakukan, kegiatan penilaian, pemberian umpan balik dan dan memberikan tugas kepada peserta didik serta menyampaikan rencana pembelajaran pada pertemuan berikutnya. ${ }^{13}$ Proses pembelajaran memiliki banyak pengertian, dan terdiri dari perencanaan pembelajaran dan pelaksaan pembelajaran, Metode, Media dan strategi. Untuk lebih singkat nya lagi tersusun pada peta konsep berikut ini :

${ }^{13}$ Lampiran Peraturan Menteri Pendidikan Nasional (Permendiknas) Nomor 41 Tahun 2007 tentang Standar Proses untuk Satuan Pendidikan Dasar dan Menengah 


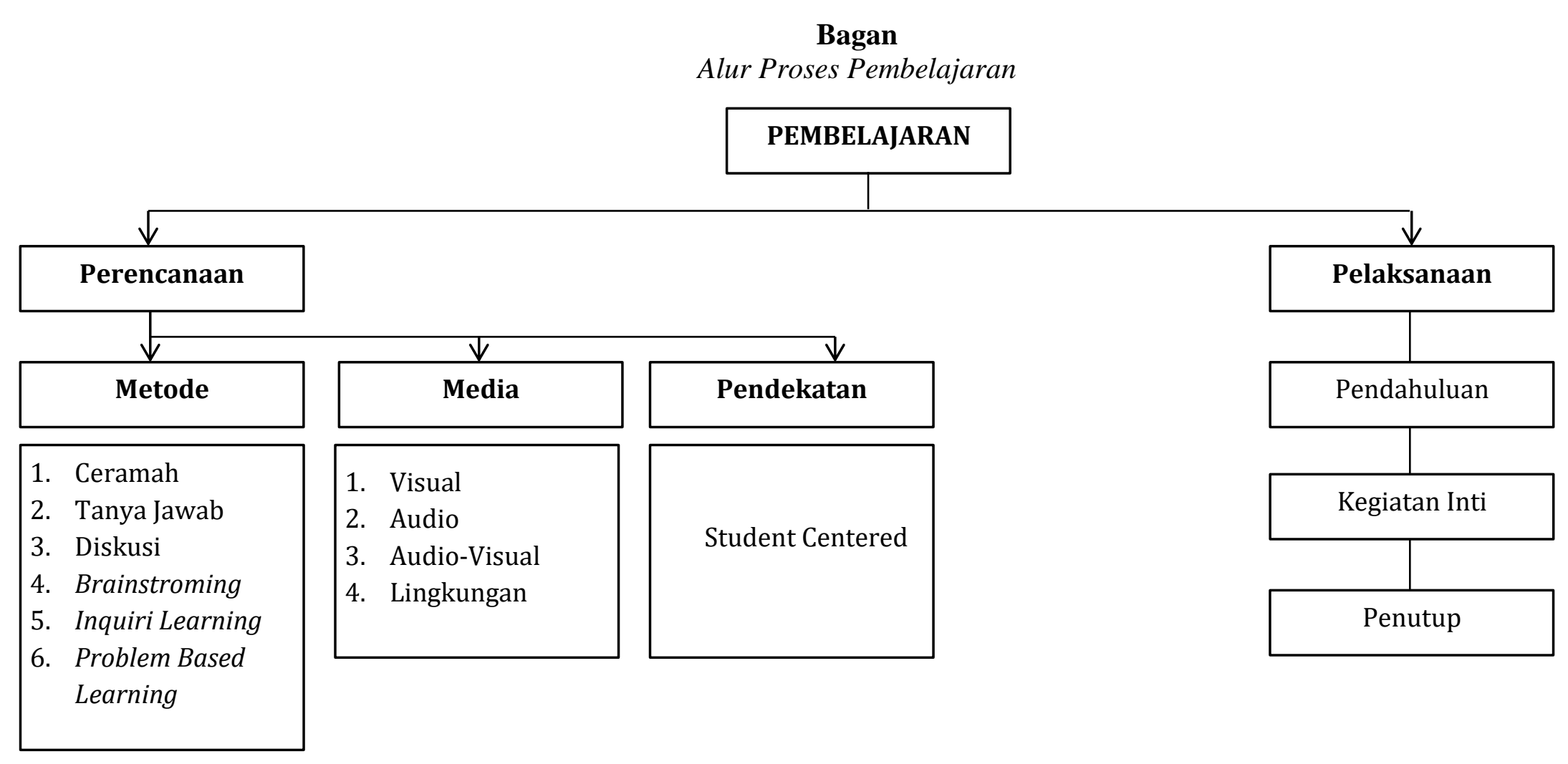




\section{Proses Pembelajaran PAI Berwawasan Kesadaran Lingkungan}

Proses pembelajaran dilaksanakan dengan mengintegrasikan materi pembelajaran dengan lingkungan hidup siswa dan lingkungan sekolah. Guru PAI membuat proses pembelajaran di kelas lebih menarik dan lebih mudah dipahami oleh siswa. Siswa diajak untuk mendiskusikan secara langsung kehidupan sehari-hari siswa dengan lingkungan dan dikaitkan dengan nilai-nilai agama yang sedang dipelajari. Oleh karena itu, pembelajaran yang dilaksanakan di SMA Negeri 1 Kedungpring merupakan pembelajaran yang menarik dan menyenangkan, serta terintegrasi dengan lingkungan sekolah. Kemudian, siswa lebih mudah mengikuti proses pembelajaran dan lebih mudah memahami materi pembelajaran yang diberikan.

Guru dan cara mengajar yang relevan dengan kebijakan sekolah Adiwiyata di SMA Negeri 1 Kedungpring diaplikasikan melalui pendekatan, strategi, metode, dan teknik pembelajaran PAI. Dilakukan melalui formulasi kegiatan atau proses pembelajaran PAI melalui penerapan pendekatan, strategi, metode, dan teknik pembelajaran yang melibatkan peserta didik secara aktif dalam pembelajaran, yaitu:

1. Metode Pembelajaran

Istilah metode adalah merupakan suatu kata yang tidak asing lagi dalam dunia pendidikan, karena setiap berlangsungnya proses pendidikan tersebut pasti akan menggunakan metode atau beberapa metode. Dalam pendidikan adan pembelajaran kata metode digunakan untuk menunjukkan serangkaian kegiatan guru terarah yang menyebabkan siswa belajar. Metode dapat pula dianggap sebagai cara atau prosedur yang keberhasilannya adalah didalam belajar atau sebagai alat yang menjadikannya mengajar menjadi efektif. ${ }^{14}$

Metode yang diterapkan dalam Pendidikan Agama Islam (PAI) untuk mewujudkan wawasan lingkungan di SMA Negeri 1 Kedungpring banyak sekali, hal ini diterapkan oleh para guru mata pelajaran Pendidikan Agama Islam dalam rangka pengintegrsian mata pelajaran kepada pendidikan lingkungan hidup. Adapun metode-metode yang digunakan, diantaranya yang terpenting adalah sebagai berikut:

a. Metode Keteladanan

Pendidikan dengan teladan berarti pendidikan dengan memberi contoh, baik berupa tingkah laku, sifat, cara berpikir, dan sebagainya. Banyak ahli pendidikan yang berpendapat bahwa pendidikan dengan teladan merupakan metode yang paling berhasil guna. Hal itu karena dalam belajar, orang pada umumnya lebih mudah menangkap yang konkret daripada yang abstrak.

Pemberian contoh atau teladan ini sangat efektif diberikan ketika guru atau orang tua ingin memberikan pelajaran mengenai pentingnya menjaga lingkungan dan alam, dari pengertian diatas guru PAI SMA Negeri 1 Kedungpring memberikan contoh dengan tidak membuang sampah sembarangan, tidak menimbulkan polusi dengan tidak merokok, dan sebagainya.

b. Metode Pembiasaan

${ }^{14}$ Abdul Aziz Wahab, Metode dan Model-Model Mengajar IPS (Bandung: Alfabeta, 2009), 36 
Pembiasaan merupakan salah satu metode pendidikan yang sangat penting, terutama bagi peserta didik. Metode pembiasaan adalah sebagai bentuk pendidikan bagi manusia yang prosesnya dilakukan secara bertahap, dan menjadikan pembiasaan itu sebagai teknik pendidikan yang dilakukan dengan membiasakan. Menurut E. Mulyasa menyatakan, metode pembiasaan adalah sesuatu yang disengaja dilakukan secara berulang-ulang agar sesuatu itu dapat menjadi kebiasaan. ${ }^{15}$ Secara teknis metode ini diimplementasikan oleh guru PAI seperti dengan adanya piket kelas yang rutin harus dilaksanakan oleh siswa SMA Negeri 1 Kedungpring setiap akan pulang dan akan memulai belajar.

c. Metode Diskusi

Metode diskusi ialah suatu cara mempelajari materi pelajaran denganmemperdebatkan masalah yang timbul dan saling mengadu argumentasisecara rasional dan objektif. Cara ini menimbulkan perhatian dan merubah tingkah laku anak dalam belajar. Zakiyah Daradjat, mengemukakan metode diskusi biasanya erat kaitannya dengan metode lainnya, seperti metode ceramah, karyawisata, dan lain-lain karena metode diskusi ini adalah bagian yang terpenting dalam memecahkan suatu masalah (problem solving). Dalam dunia pendidikan metode diskusi ini mendapat perhatian karena dengan diskusi akan merangsang murid-murid berpikir atau mengeluarkan pendapat sendiri. ${ }^{16}$

Dari pengertian diatas guru PAI SMA Negeri 1 Kedungpring melakukan pembelajaran kolaboratif penelitian mini yang kemudian dibentuk kelompokkelompok diskusi untuk memaparkan hasil mini research tersebut. Tujuan dari mini reseach ini adalah siswa mendapatkan pengetahuan tidak hanya sekedar dalam bentuk teori secara verbal tapi juga melihat secara langsung. Materi yang diterapkan dengan metode ini adalah materi tentang kerusakan alam.

2. Bahan Ajar

Bahan ajar adalah seperangkat sarana atau alat pembelajaran yang berisikan materipembelajaran, metode, batasan-batasan, dan cara mengevaluasi yang didesain secara sistematis dan menarik dalam rangka mencapai tujuan yang diharapkan, yaitu mencapai kompetensi atau subkompetensi dengan segala kompleksitasnya. ${ }^{17}$ Pengertian ini menjelaskan bahwa suatu bahan ajar haruslah dirancang dan ditulis dengan kaidah intruksional karena akan digunakan oleh guru untuk membantu dan menunjang proses pembelajaran.

Guru PAI di SMA Negeri 1 Kedungpring dalam proses pembelajaran menggunakan buku guru dan buku siswa sebagai bahan atau sumber materi ajar. Buku guru dan siswa yang diterbitkan oleh Kementerian Pendidikan dan Kebudayaan yaitu "Pendidikan Agama Islam dan Budi Pekerti" namun selama ini

${ }^{15}$ E. Mulyasa, Manajemen Pendidikan Agama Islam Berbasis Kompetensi (Bandung: PT Remaja Rosdakarya, 2005), 166

16 Zakiyah Daradjat, Metodik Khusus Pengajaran Agama Islam (Jakarta: Bumi Aksara,dengan Direktoral Jenderal Pembinaan Kelembagaan Agama Islam Departemen Agama, 2004), 292

${ }^{17}$ Ika Lestari dkk, Pengembangan Bahan Ajar Berbasis Kompetensi (Padang: Akademia Permata, 2013), 1 
dirasakan belum cukup untuk menjadi acuan dasar dalam pengimplementasian pembelajaran PAI berwawasan lingkungan di SMA Negeri 1 Kedungpring.

3. Media Pembelajaran

Gerlach dan Ely menjelaskan bahwa media pembelajaran apabila dipahami secara garis besar adalah manusia, materi atau kejadian yang membangun kondisi yang membuat siswa mampu memperoleh pengetahuan, ketrampilan atau sikap. Dalam pengertian ini, guru, buku teks, dan lingkungan sekolah merupakan media. Secara khusus, pengertian media dalam proses pembelajaran cenderung diartikan sebagai alat-alat grafis, photografis, atau elektronikuntuk menangkap, memproses dan menyusun kembali informasi visual atau verbal. ${ }^{18}$

Pemakaian media pembelajaran dalam proses belajar mengajar dapat membangkitkan minat dan keinginan yang baru, motivasi dan rangsangan kegiatan belajar, dan bahkan membawa pengaruh-pengaruh psikologis terhadap siswa. Penggunaan media pembelajaran pada tahap orientasi pengajaran akan sangat membantu keefektifan proses pembelajaran dan penyampaian pesan dan isi pelajaran pada saat itu, sehingga yang menjadi tujuan dari pembelajaran bias tercapai secara maksimal.

Media pembelajaran yang digunakan dalam pembelajaran adalah laptop, LCD dan video. Pengunaan laptop, LCD dan video pada saat KBM untuk menampilkan contoh nyata tentang keadaan yang berhubungan dengan materi yang diajarkan. seperti contohnya pada saat guru PAI SMA Negeri 1 Kedungpring mengajarkan materi tentang perintah menjaga kelestarian lingkungan hidup, guru menampilkan video tentang banjir atau tanah longsor akibat penebangan hutan secara liar.

\section{Desain Instruksional PAI Berbasis Kesadaran Lingkungan}

Desain instruksional (pembelajaran) agama Islam di SMA Negeri 1 Kedungpring menuntut seorang pendidik/guru agar mengetahui dan mempelajari desain apakah yang yang perlu dipertimbangkan pada model kegiatan pembelajaran yang akan dilaksanakan, dimana dari desain tersebut seorang guru dapat membantu peserta didik dalam proses pembelajaran.

Herbert Simon (Dick and Cerey) mengatakan, desain pembelajaran adalah proses untuk memecahkan permasalahan. Sedangkan tujuannya adalah untuk memecahkan masalah dengan memanfaatkan sejumlah informasi yang sudah tersedia. ${ }^{19}$

Guru PAI di SMA Negeri 1 Kedungpring dalam mendesain pembelajaran adalah dengan mempersiapkan RPP (Rencana Pelaksanaan Pembelajaran) dengan baik yang tentu terlebih dahulu melihat kondisi peserta didik di dalam menentukan materi termasuk pada materi tentang lingkungan yang menggunakan berbagai strategi, metode dan media.

Manfaat atau tujuan desain pembelajaran adalah untuk menilai pengajaran atau keadaan siswa artinya pengajaran dinilai berhasil apabila siswa telah mencapai

${ }^{18}$ Azhar Arsyad, Media Pembelajaran (Jakarta: Raja Grafindo Persada, 2000), 3

${ }^{19}$ Wina Sanjaya, Perencanaan dan Desain Sistem Pembelajaran (Jakarta: Kencana Prenada Medi Group, 2006), 65 
tujuan pengajaran yang telah ditentukan. Ketercapaian tujuan-tujuan pengajaran oleh siswa menjadi indikator keberhasilan system pengajaran yang dirancang sebelumnya.

Desain pembelajaran guru PAI di SMA Negeri 1 Kedungpring menuntut agar mengetahui dan mempelajari desain yang perlu dipertimbangkan pada tujuan pembelajaran, proses pembelajaran, strategi pembelajaran, dan teknik penilaian pembelajaran yang akan digunakan sebagai berikut:

\section{Tujuan Pembelajaran}

Robert F. Mager mendefinisikan tujuan pembelajaran adalah perilaku yang hendak dicapai atau yang dapat dikerjakan oleh siswa pada kondisi dan tingkat kompetensi tertentu. ${ }^{20}$ Melalui rumusan tujuan pembelajaran ini dapat dilihat pengalaman belajar seperti apakah yang akan diberikan kepada peserta didik untuk dapat mencapai suatu kompetensi tertentu. Dengan kata lain, tujuan pembelajaran ini merupakan rumusan pernyataan spesifik yang menjelaskan tentang apa hasil perubahan yang akan diperoleh oleh siswa setelah mengikuti proses pembelajaran dan melalui cara bagaimana proses pembelajaran tersebut akan dilakukan.

Tujuan pembelajaran PAI berwawasan lingkungan di SMA Negeri 1 Kedungpring tertuang dalam perencanaan/desain pembelajaran yang dilakukan oleh Guru PAI baik secara individu maupun tim dengan melengkapi administrasi pembelajaran yang meliputi penyusunan silabus, program semester, Kriteria Ketuntasan Minimal (KKM), kisi-kisi soal serta Rencana Pelaksanaan Pembelajaran (RPP) untuk setiap tahun pelajaran.

Secara lebih rinci, terdapat beberapa aspek mendasar dalam pelaksanaannya tujuan pembelajaran, aspek tersebut antara lain:

a. Silabus

Silabus yang dijadikan acuan guru PAI dalam pengimplemantasian pembelajaran. Dalam silabus pembelajaran PAI, beberapa point yang mengandung muatan tujuan PAI berwawasan lingkungan tertuang dalam pengembangan materi pembelajaran dan kegiatan pembelajaran yang harus mengintegrasikan muatan lingkungan hidup di dalamnya. Guru PAI di SMA Negeri 1 Kedungpring mengintegrasikan materi tersebut ke dalam pendidikan lingkungan, sehingga materi PAI selaras dengan kebijakan sekolah tentang program Adiwiyata.

b. Rencana Pelaksanaan Pembelajaran (RPP)

Dalam penyusunan Rencana Pelaksanaan Pembelajaran (RPP) mata pelajaran Pendidikan Agama Islam (PAI) di SMA Negeri 1 Kedungpring, penyampaian materi lingkungan hidup pada mata pelajaran PAI kepada peserta didik sejatinya dapat dilakukan melalui penyusunan RPP baik secara terintegrasi atau monolitik. Misalnya tujuan pembelajaran dari QS. Al-Baqarah ayat 4 atau bahkan QS. Ar-Rum ayat 41-42, diharapkan peserta didik lebih bertqwa kepada 
Allah SWT dan juga agar lebih disiplin dalam menjaga lingkungan agar rasa kepeduliaan lingkungannya semakin meningkat.

2. Proses Pembelajaran

Proses pembelajaran PAI berwawasan kesadaran lingkungan di SMA Negeri 1 Kedungpring dilaksanakan tentu tidak lepas dari kegiatan belajar mengajar sebagai inti kegiatan pada suatu lemabaga pendidikan. Melalui pembelajaran di dalam kelas ini berpeluang besar untuk menginternalisasikan/menyampaikan nilai-nilai kesadaran lingkungan kedalam pelajaran pendidikan agama Islam.

Guru PAI biasanya memberikan dengan bentuk penugasan yang diberikan untuk dikerjakan kepada peserta didik mengamati lingkungan sekitar yang dikemudian dikaitkan dengan materi pembelajaran yang sudah mereka pelajari. Kegiatan ini mendukung siswa memperluas wawasan pengetahuan yang telah mereka dapatkan di dalam kelas, seperti mengadakan pembelajaran di luar kelas (outdoor) dengan tujuan selain untuk membuat peserta didik tidak bosan dengan pelajaran di kelas.

3. Strategi Pembelajaran

Untuk mendukung suksesnya pelaksanaan pembelajaran diperlukan adanya strategi dalam pembelajaran. Strategi pembelajaran merupakan suatu serangkaian rencana kegiatan yang termasuk didalamnya pengunaan metode dan pemanfaatan berbagai sumber daya atau kekuatan dalam suatu pembelajaran. Strategi Pembelajaran adalah suatu kegiatan pembelajaran yang harus dikerjakan guru dan siswa agar tujuan pembelajaran dapat dicapai secara efektif dan efisien.

Dari guru PAI di SMA Negeri 1 Kedungpring menggunakan strategi pembelajaran berdasarkan masalah (problem based learning), siswa diberikan permasalahan atau mereka tentukan masalah yang aktual terkait dengan lingkungan hidup, soal sampah atau pencemaran lingkungan misalnya, bagaimana mengatasinya. Strategi ini sangat baik untuk memberi tanggung jawab siswa dalam memahami masalah lingkungan hidup dan cara mengatasinya, sehingga menimbulkan kesadaran untuk tidak melakukan hal yang sama, dan lebih peduli dalam menjaga ekosistem lingkungan.

4. Teknik Penilaian

Guru PAI di SMA Negeri 1 Kedungpring dalam pengelolaan evaluasi dan penilaian pembelajaran dilakukan menggunakan instrumen authentic assessment dengan cara mengembangkan indikator dan instrumen penilaian pembelajaran PAI yang terintegrasi pada lingkungan hidup, artinya bahwa pembelajaran PAI dan lingkungan hidup baik secara integrasi maupun monolitik harus dilengkapi dengan indikator penilaian tingkat keberhasilan.

\section{Kesimpulan}

Berdasarkan pembahasan diatas maka dapat disimpulkan bahwa Proses Proses pembelajaran PAI berwawasan kesadaran lingkungan di SMA Negeri 1 Kedungpring adalah melalui program adiwiyata. Dilakukan melalui formulasi kegiatan atau proses pembelajaran PAI melalui penerapan metode pembelajaran antara lain melalui keteladanan, pembiasaan dan diskusi. 
Sedangkan dalam bahan ajarnya, guru PAI menggunakan buku guru dan buku siswa, selain itu juga menggunakan referensi-referensi lain yang terkait dengan setiap materi yang disampaikan baik yang di sediakan oleh sekolah dan Modul yang disusun. Selain itu, media pembelajaran mengadopsi media yang berbasis pada IT, antara lain laptop, LCD dan video. Desain instruksional (pembelajaran) PAI berbasis kesadaran lingkungan di SMA Negeri 1 Kedungpring menuntut seorang pendidik/guru agar mengetahui dan mempelajari desain apakah yang yang perlu dipertimbangkan pada: pertama, tujuan Pembelajaran: tertuang dalam perencanaan/desain pembelajaran yang dilakukan oleh Guru PAI baik secara individu maupun tim dengan melengkapi administrasi pembelajaran, yaitu silabus dan RPP. Kedua, Proses Pembelajaran: dalam proses pembelajaran dilakukan di dalam kelas, guru PAI juga biasanya memberikan dengan bentuk penugasan dan mengadakan pembelajaran di luar kelas (outdoor). Ketiga, strategi Pembelajaran: guru PAI menggunakan strategi pembelajaran berdasarkan masalah (problem based learning). Keempat, teknik Penilaian: dalam pengelolaan evaluasi dan penilaian pembelajaran guru PAI menggunakan instrumen authentic assessment.

\section{Daftar Rujukan}

Arifin, Zainal. Evaluasi Pembelajara. Bandung: PT Remaja Rosdakarya, 2012.

Arsyad, Azhar. Media Pembelajaran. Jakarta: Raja Grafindo Persada, 2000.

Daradjat, Zakiyah. Metodik Khusus Pengajaran Agama Islam. Jakarta: Bumi Aksara. 2004.

Djamarah, Syaiful Bahri. Guru dan Anak Didik. Jakarta: Rineka Cipta, 2010.

Djumransjah, M. Filsafat Pendidikan. Malang: Bayumedia Publishing, 2004.

Glendoni. Komponen-Komponen Pembelajaran, diakses 30 Oktober 2013

Kutanegara, Pande Made. Membangun Masyarakat Indonesia Peduli Lingkungan. Yogyakarta: Gadjah Mada University Press, 2014.

Lampiran Peraturan Menteri Pendidikan Nasional (Permendiknas) Nomor 41 Tahun 2007 tentang Standar Proses untuk Satuan Pendidikan Dasar dan Menengah

Lestari dkk, Ika. Pengembangan Bahan Ajar Berbasis Kompetensi. Padang: Akademia Permata, 2013.

Mulyasa, E. Pendidikan Agama Islam Berbasis Kompetensi. Bandung: PT Remaja Rosdakarya, 2005.

Mulyasana, Dedi. Pendidikan Bermutu dan Berdaya Saing. Bandung: PT. Remaja Rosdakarya, 2012.

Munchit, M. Saekhan. Pembelajaran Konstekstual. Semarang: RaSAIL Media Group, 2008. Nasution. Metode Penelitian Naturalistic Kualitatif. Bandung: Tarsito, 2002.

Neolaka, Amos. Kesadaran Lingkungan. Jakarta: Rineka Cipta, 2008. 
Peraturan Menteri Pendidikan Nasional No.41 tahun 2007 pasal 1 tentang standar proses penmbelajaran untuk satuan menengah

Sagala, Syaiful. Konsep dan Makna Pembelajaran. Bandung : ALFABETA, 2008.

Sanjaya, Wina. Perencanaan dan Desain Sistem Pembelajaran. Jakarta: Kencana Prenada Media Group, 2008.

Tauhied, H. Abu. Beberapa Aspek Pendidikan Islam. Yogyakarta: Fak. Tarbiyah UIN Sunan Kalijaga, 1990.

Uno, Hamzah B. Perencanaan Pembelajaran. Jakarta: Bumi Aksara, 2008.

Wahab, Abdul Aziz. Metode dan Model-Model Mengajar IPS. Bandung: Alfabeta, 2009. 